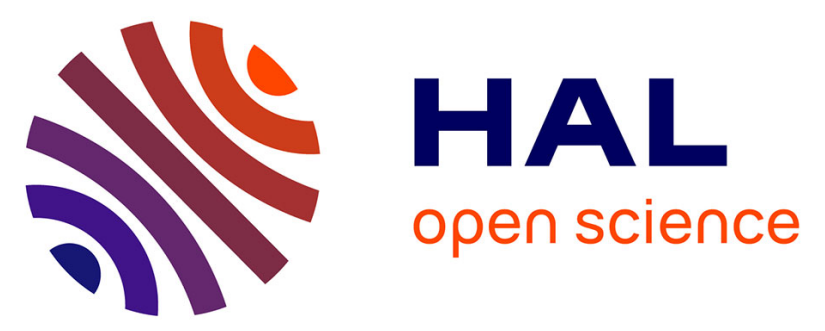

\title{
Bridging the knowledge gap on mycoses in Africa: Setting up a Pan-African Mycology Working Group
}

Rita O Oladele, Iorhen E Akase, Ahmed H Fahal, Nelesh P Govender, Martin Hoenigl, Jean Pierre Gangneux, Tom M Chiller, David W Denning, Oliver A Cornely, Arunaloke Chakrabarti

\section{To cite this version:}

Rita O Oladele, Iorhen E Akase, Ahmed H Fahal, Nelesh P Govender, Martin Hoenigl, et al.. Bridging the knowledge gap on mycoses in Africa: Setting up a Pan-African Mycology Working Group. Mycoses, 2020, 63 (3), pp.244-249. 10.1111/myc.13044 . hal-02441218

HAL Id: hal-02441218

https://hal-univ-rennes1.archives-ouvertes.fr/hal-02441218

Submitted on 12 Feb 2020

HAL is a multi-disciplinary open access archive for the deposit and dissemination of scientific research documents, whether they are published or not. The documents may come from teaching and research institutions in France or abroad, or from public or private research centers.
L'archive ouverte pluridisciplinaire HAL, est destinée au dépôt et à la diffusion de documents scientifiques de niveau recherche, publiés ou non, émanant des établissements d'enseignement et de recherche français ou étrangers, des laboratoires publics ou privés. 
DR RITA OLADELE (Orcid ID : 0000-0003-1488-3345)

DR NELESH PREMAPRAGASAN GOVENDER (Orcid ID : 0000-0001-7869-9462)

DR MARTIN HOENIGL (Orcid ID : 0000-0002-1653-2824)

DR JEAN PIERRE GANGNEUX (Orcid ID : 0000-0002-4974-5607)

PROFESSOR OLIVER A. CORNELY (Orcid ID : 0000-0001-9599-3137)

Article type : Review Article

Bridging the knowledge gap on mycoses in Africa; setting up a Pan-African Mycology Working Group

Oladele RO${ }^{1}$, Akase $\mathrm{IE}^{2}$, Fahal $\mathrm{A}^{3}$, Govender $\mathrm{NP}^{4}$, Honigl M${ }^{5,6}$, Gangneux $\mathrm{JP}^{7}$, Chiller $\mathrm{TM}^{8}$, Denning $\mathrm{DW}^{9}$, Cornely $\mathrm{OA}^{10}$ and Chakrabarti $\mathrm{A}^{11}$

1 Department of Medical Microbiology \& Parasitology, College of Medicine University of Lagos

2 Department of Medicine, Lagos University Teaching Hospital, Lagos, Nigeria

3 The Mycetoma Research Centre, Khartoum, Sudan

${ }^{4}$ National Institute for Communicable Diseases, a Division of the National Health Laboratory Service and University of the Witwatersrand, Johannesburg, South Africa.

${ }^{5}$ Division of Infectious Diseases and Global Public Health University of California San Diego, USA ${ }^{6}$ Section of Infectious Diseases and Tropical Medicine, Medical University of Graz, Austria 
${ }^{7}$ CHU de Rennes, Univ Rennes, Inserm, Irset (Institut de recherche en santé, environnement et travail) - UMR_S, 1085, Rennes, France

${ }^{8}$ Centers for Disease Control and Prevention (CDC), Atlanta, GA, USA.

${ }^{9}$ Global Action Fund for Fungal Infections, Geneva, Switzerland and the University of Manchester, Manchester, UK.

${ }^{10}$ Department I of Internal Medicine, European Diamond Excellence Center of Medical Mycology, University Hospital Cologne; Cologne Excellence Cluster on Cellular Stress Responses in Aging-Associated Diseases (CECAD); and Clinical Trials Centre Cologne (ZKS Köln), University of Cologne, Cologne, Germany. ${ }^{11}$ Department of Medical Microbiology, Postgraduate Institute of Medical Education \& Research Chandigarh, India

Correspondence

Rita O. Oladele,

Department of Medical Microbiology \& Parasitology, College of Medicine of University of Lagos,

Lagos, Nigeria.

Email: oladelerita@gmail.com

All authors contributed equally to the development of this manuscript

No Conflict of Interest 


\section{Abstract}

Most African countries have poorly funded and overburdened health systems. Additionally, a high prevalence of HIV in Sub-Saharan Africa contributes to a high burden of opportunistic fungal infections. Data generated by GAFFI from 15 of 57 African countries revealed that an estimated 47 million Africans suffer from fungal diseases, of whom an estimated 1.7 million suffer from a serious fungal infection annually. Almost all African countries lack a surveillance system for fungal infections with the exception of South Africa. South Africa is also the only African country with a national mycology reference laboratory. Across the continent, there is a pervasive picture of inadequate/poor diagnostic capacity, low level of awareness among health care workers and policy makers as well as unavailability and nonaccessibility to essential antifungal medications. Recent outreach efforts by the International Society for Human and Animal Mycology (ISHAM) and the European Confederation of Medical Mycology (ECMM) have aimed to increase involvement of African countries and experts in global initiatives such as "One World One Guideline" and also the ECMM Academy. Recently, under the auspices of ISHAM, the African sub-region created a network of mycology experts whose goal is organize and engage African leaders in the field of medical mycology. The aim of this ISHAM Working Group is to facilitate interaction and synergy among regional leaders in order to develop educational programs for capacity building to aid in the diagnosis and care of patients with fungal infections in Africa. The working group will also encourage country initiatives to develop clinical guidelines, to support surveys, and to support the establishment of reference mycology laboratories. 


\section{Introduction}

Fungal pathogens are a growing threat globally. Over a billion people are directly affected by mycoses globally, 150 million of who have a serious or life threatening infection. ${ }^{1}$ More than 1.6 million people die of fungal diseases each year: $\sim 500,000$ of which are AIDS-related and 450,000 are thought to be due to chronic pulmonary aspergillosis. The African continent has an estimated population of 1.3 billion people accounting for roughly about a fifth of the world's population and about $75 \%$ of all the 37 million human immunodeficiency virus (HIV) infected people. Approximately $50 \%$ fungal related deaths in the setting of HIV infections probably occur in Africa, although vital statistics are missing from most African countries. ${ }^{2}$ From the data generated by GAFFI (Global Action Funds for Fungal Infections); an estimated 47.6 million Africans suffer from fungal diseases, of which 1.7 million suffer from a serious fungal infection annually. ${ }^{3}$ This is particularly alarming since these estimates are based on data from only 15 (of 57) African countries (table 1). Almost all African countries lack a surveillance system for fungal infections; the only exception is South Africa. Only South Africa has a national mycology reference laboratory.

\section{Table 1: Estimated burden of fungal infections in Africa}

Africa is endemic for histoplasmosis (including African histoplasmosis caused by $H$. capsulatum var duboisii), emergomycosis, mycetoma, chromoblastomycosis and several other endemic fungi. Among patients with HIV infection, cryptococcal meningitis and Pneumocystis pneumonia are a common cause of death among many African patients. Additionally, invasive candidiasis and aspergillosis and chronic pulmonary aspergillosis, fungal asthma, fungal keratitis and tinea infections all contribute to significant morbidity and mortality. A systematic review on fungal keratitis revealed an estimate of 13.5/100,000 annually in Africa. ${ }^{19}$ Certain fungal infections are peculiar to or more common among Africans (see Table 2) while others are rarely reported in Africa, including adiaspiromycosis, lobomycosis, blastomycosis and sporotrichosis. ${ }^{20}$ This may not necessarily be due to absence of the diseases but due to lack of diagnostic capacity. 
Figure 1: Documented burden of fungal infections across Africa ${ }^{2}$

Table 2: Description of some fungal infections which are unique to Africa ${ }^{20}$

Other endemic mycoses are not endemic in Africa and may be imported, including talaromycosis, coccidioidomycosis and paracoccidioidomycosis ${ }^{21}$ Precise data on the true prevalence of fungal infections is unavailable in most parts in Africa, which is especially pronounced for African histoplasmosis and blastomycosis, In contrast, the epidemiology of mycetoma, cryptococcosis, emergomycosis and Candida auris has been better described in some areas. This is due to (1) extensive work that has been done and is still on-going by van de Sande and Fahal research teams (mycetoma in Sudan) which has led to the establishment of a WHO Collaborating Centre in Sudan; (2) The relationship of HIVIAIDS (sub-Saharan Africa bears a significant part of the burden globally) and cryptococcal meningitis; (3) the presence of a defined public health agenda, a mycology reference laboratory and national surveillance network in South Africa, which has aided Govender and other researchers to describe the epidemiology of emergomycosis, cryptococcal meningitis and candidaemia (caused by emerging azole-resistant pathogens such as Candida auris ${ }^{22}$ and Candida parapsilosis ${ }^{23}$ ). The recent revolution in non-culture based diagnostics has yet to penetrate in Africa, with the one partial exception of cryptococcal antigen testing. For example, PCR for Pneumocystis was first described in $1991^{24}$ was commercialised and standardised in $2011,{ }^{25}$ but is not yet used diagnostically in Africa (except in South Africa), despite multiple studies showing its clinical value, especially in children. Many fungi cannot easily be grown under lab conditions (or plates get contaminated in non-air conditioned laboratories), and culturing is time consuming and requires specialist training; thus, there is a need for diagnostics that can be widely applied by laboratory technicians lacking traditional fungal identification skills and facilities.

Against the high burden of fungal infections in Africa, most African countries have poorly funded and overburdened health systems. Additionally, there is a pervasive picture of inadequate/ poor diagnostic capacity, low level of awareness among health care workers 
and policy makers, unavailability and non-accessibility of antifungal medications. Data from GAFFI website shows that among the 56 territories and countries in Africa, amphotericin B is not registered in 12 and unavailable in 25, fluconazole is not registered in 8 and unknown in 6 itraconazole not registered in 23 and unavailable in 23 , while voriconazole is registered in only 12 countries and available only in 12, with flucytosine registered in three countries and available in only 1 country. ${ }^{26,27}$

The African continent has not previously developed a network of mycology experts whose goal is to provide a common platform for a comprehensive discussion and collaboration on fungal infections. The result of this lack of networked expertise has been uncoordinated activity of various scientists, clinicians, academicians and societies, sometimes duplicating efforts but more commonly being relatively ineffective, in terms of addressing the knowledge gaps in diagnosing and managing patients with fungal infections. The Africa Fund for Fungal Biodiversity and Mycotic Infections, initiated by G. Sybren de Hoog and Jacques F. Meis in 2014, organized and funded the inauguration of the Pan-African Medical Mycology Society (PAMMS) during a meeting entitled 'Medical Mycology: The African Perspective' on 25 Jan 2005 in Hartenbos (South Africa). ${ }^{28}$ In 2007 the second PAMMS meeting was held in Cape Town and the third in 2009 in Abuja, Nigeria. After this last meeting, 10 years ago, PAMMS fell away mostly due to the lack of leadership and possibly failure to include physicians. Recent renewed outreach efforts of ISHAM and also the European Confederation of Medical Mycology (ECMM) have aimed to increase involvement of African countries and experts in e.g. the "One World One Guideline" initiative ${ }^{29}$ and also the ECMM Academy. ${ }^{30}$ A network of mycology experts is required in Africa to provide a regional critical mass and common platform for clinical, laboratory, public education and collaboration on fungal infections. Expertise and data are required in each country.

The Pan-African Mycology Working Group (PAMWG) has been set up to organize and engage African leaders in the field of medical mycology in the African sub-region, linked to ISHAM. The aim of this Working Group for African clinicians, microbiologists, scientists, pharmacists and technicians is to provide a better interaction and synergy among regional 
leaders in order to develop educational programs for capacity building to aid in the diagnosis and care of patients with fungal infections in Africa. The Working Group will also encourage country initiatives to develop clinical guidelines for the management of fungal infections and to support surveys and support the establishment of Mycology Reference Laboratories.

\section{Mission}

The PAMWG is an ISHAM working group composed of health-care professionals involved with mycology devoted to the understanding, diagnosis and management of invasive fungal infections, as well as the collation of fungal surveillance data for best outcomes of patients at risk of, or who are diagnosed with fungal infections in Africa.

\section{Objectives}

The ISHAM PAMWG aims to provide a platform for all the leaders in the field of mycology from multiple African countries in order to initiate epidemiological studies, regional guidelines, and educational programs to increase the capacity/ expertise of African specialists in the early detection and treatment of fungal infections. Additionally, we will be committed to advocacy activities to guide policy makers to provide the necessary support for the care of patients with fungal infections.

These activities will be fulfilled through the following activities;

- Education and training programs for health care workers involved in the care and evaluation of patients with fungal infections.

- South-south, and north-south collaborations and partnership.

- Organization of regional collaborative studies in the field of medical mycology.

- Encourage all PAMWG members to become members of ISHAM

- Organize local meetings in African countries in collaboration with ISHAM

- Assist PAMWG members to attend international congresses organized by ISHAM and ECMM

- To ensure that fungal diseases in Africa are no longer neglected by bridging knowledge gaps 
Political will is essential in tackling the scourge of serious fungal infections in affected countries Presently, there is no government resource allocation for surveillance, diagnostic facilities, outbreak response, epidemiological study and control of fungal infections, especially the life-threatening ones in Africa (apart from South Africa). Meeting the objectives listed above will generate the key data for advocacy needed to drive government commitment to allocate the resources required.

\section{References}

1. Bongomin F, Gago S, Oladele RO, Denning DW. Global and Multi-National Prevalence of Fungal Diseases-Estimate Precision. J Fungi (Basel). 2017 Oct 18;3(4):57. doi: 10.3390/jof3040057. PMID: 29371573; PMCID: PMC5753159.

2. Denning DW. Minimizing fungal disease deaths will allow the UNAIDS target of reducing annual AIDS deaths below 500000 by 2020 to be realized. Philos Trans $R$ Soc Lond B Biol Sci. 2016 Dec 5;371(1709):20150468. doi:10.1098/rstb.2015.0468.

3. GAFFI - Global Action Fund for Fungal infections. Antifungal drug maps. Available at https://www.gaffi.org/antifungal-drug-maps/. Accession date $4^{\text {th }}$ July 2019

4. Chekiri-Talbi M, Denning DW. Burden of fungal infections in Algeria. European Journal of Clinical Microbiology \& Infectious Diseases. 2017 Jun 1;36(6):999-1004.

5. Bamba S, Zida A, Sangaré I, Cissé M, Denning D, Hennequin C. Burden of severe fungal infections in Burkina Faso. Journal of Fungi. 2018 Mar;4(1):35.

6. Mandengue $C$, Denning $D$. The burden of serious fungal infections in Cameroon. Journal of Fungi. 2018 Jun;4(2):44.

7. Zaki SM, Denning DW. Serious fungal infections in Egypt. European Journal of Clinical Microbiology \& Infectious Diseases. 2017 Jun 1;36(6):971-4.

8. Tufa TB, Denning DW. The Burden of Fungal Infections in Ethiopia. Journal of Fungi. 2019 Dec;5(4):109.

9. Ocansey BK, Pesewu GA, Codjoe FS, Denning DW. The burden of serious fungal infections in Ghana. Journal of Infection and Public Health. 2019 Jan 1;12(1):124-5. 
10. Guto JA, Bii CC, Denning DW. Estimated burden of fungal infections in Kenya. The Journal of Infection in Developing Countries. 2016 Aug 31;10(08):777-84.

11. Kalua K, Zimba B, Denning D. Estimated burden of serious fungal infections in Malawi. Journal of Fungi. 2018 Jun;4(2):61.

12. Sacarlal J, Denning D. Estimated burden of serious fungal infections in Mozambique. Journal of Fungi. 2018 Sep;4(3):75.

13. Dunaiski CM, Denning DW. Estimated Burden of Fungal Infections in Namibia. Journal of Fungi. 2019 Sep;5(3):75.

14. Oladele RO, Denning DW. Burden of serious fungal infection in Nigeria. West Afr J Med. 2014 Apr;33(2):107-14.

15. Badiane AS, Ndiaye D, Denning DW. Burden of fungal infections in Senegal. Mycoses. 2015 Oct;58:63-9.

16. Schwartz IS, Boyles TH, Kenyon CR, Hoving JC, Brown GD, Denning DW. The estimated burden of fungal disease in South Africa. SAMJ: South African Medical Journal. 2019 Nov;109(11):885-92.

17. Faini D, Maokola W, Furrer H, Hatz C, Battegay M, Tanner M, Denning DW, Letang E. Burden of serious fungal infections in Tanzania. Mycoses. 2015 Oct;58:70-9.

18. Parkes-Ratanshi R, Achan B, Kambugu A, Meya D, Denning D. Estimated burden of fungal disease in Uganda. Tropical medicine \& international health: TM \& $\mathrm{IH}$. 2007;12:929-35.

19. Brown L, Burton, Gichangi M and Denning DW. The Global Incidence of Fungal Keratitis. In Press

20.Pfaller MA, Diekema DJ. Unusual fungal and pseudofungal infections of humans. Journal of clinical microbiology. 2005 Apr 1;43(4):1495-504.

21. Jacyk WK, Lawande RV, Tulpule SS. Deep mycoses in West Africa: a report of 13 cases and review of the Nigerian literature. Journal of the National Medical Association. $1981 \mathrm{Mar} ; 73(3): 251$.

22. Lone SA, Ahmad A. Candida auris-the growing menace to global health. Mycoses. 2019 Feb 17. 
23. Magobo RE, Naicker SD, Wadula J, Nchabeleng M, Coovadia Y, Hoosen A, et al. Detection of neonatal unit clusters of Candida parapsilosis fungaemia by microsatellite genotyping: Results from laboratory-based sentinel surveillance, South Africa, 2009-2010. Mycoses. 2017 May;60(5):320-7.

24. Wakefield AE, Guiver L, Miller RF, Hopkin JM. DNA amplification on induced sputum samples for diagnosis of Pneumocystis carinii pneumonia. The Lancet. 1991 Jun 8;337(8754):1378-9.

25. Hauser PM, Bille J, Lass-Flörl C, Geltner C, Feldmesser M, Levi M, Patel H, Muggia V, Alexander B, Hughes M, Follett SA. Multicenter, prospective clinical evaluation of respiratory samples from subjects at risk for Pneumocystis jirovecii infection by use of a commercial real-time PCR assay. Journal of clinical microbiology. 2011 May 1;49(5):1872-8.

26. Kneale M, Bartholomew JS, Davies E, Denning DW. Global access to antifungal therapy and its variable cost. Journal of Antimicrobial Chemotherapy. 2016 Aug 10;71(12):3599-606.

27. Skiada A, Pavleas I, Drogari-Apiranthitou M. Rare fungal infectious agents: a lurking enemy. F1000Research. 2017;6.

28. Mycology Newsletter (ECMM) 2005;9(1):4-5. Accessed 29 th Nov 2019. Available at http://www.ecmm.eu/ECMM_N09_1_2005_A3.pdf

29. Cornely OA, Alastruey-Izquierdo A, Arenz D, Chen SC, Dannaoui E, Hochhegger B, et al. Global guideline for the diagnosis and management of mucormycosis: An initiative of the European Confederation of Medical Mycology in cooperation with the Mycoses Study Group Education and Research Consortium. The Lancet Infectious Diseases. 2019; 19(12):e405-e421.

30. Hoenigl M, Gangneux JP, Segal E, Alanio A, Chakrabarti A, Chen SC, Govender N, Hagen F, Klimko N, Meis JF, Pasqualotto AC, Seidel D, Walsh TJ, Lagrou K, LassFlörl C, Cornely OA; European Confederation of Medical Mycology (ECMM). Global guidelines and initiatives from the European Confederation of Medical Mycology to 
improve patient care and research worldwide: New leadership is about working together. Mycoses. 2018 Nov;61(11):885 
Table 1: Estimated burden of fungal infections in Africa

\begin{tabular}{|c|c|c|c|c|c|c|c|c|}
\hline Country & $\begin{array}{l}2019 \\
\text { Popu } \\
\text { latio } \\
\mathrm{n} \\
\text { (milli } \\
\text { on) }\end{array}$ & $\begin{array}{l}\text { Total } \\
\text { burden } \\
\text { of } \\
\text { serious } \\
\text { fungal } \\
\text { infectio } \\
\text { n }\end{array}$ & $\begin{array}{l}\text { oesoph } \\
\text { ageal } \\
\text { candidi } \\
\text { asis }\end{array}$ & $\begin{array}{l}\text { oral } \\
\text { candidia } \\
\text { sis }\end{array}$ & RVVC & $\begin{array}{l}\text { Fungal } \\
\text { keratiti } \\
\text { s }\end{array}$ & $\begin{array}{l}\text { Tinea } \\
\text { capitis }\end{array}$ & $\begin{array}{l}\text { Serious } \\
\text { fungal } \\
\text { infection } \\
\text { s }\end{array}$ \\
\hline Algeria $^{4}$ & 42.63 & 568,942 & 832 & & $\begin{array}{l}485,18 \\
8\end{array}$ & & 4,265 & 78657 \\
\hline B/ Faso ${ }^{5}$ & 20.28 & $\begin{array}{l}1,360,28 \\
0\end{array}$ & 7,450 & 24,300 & $\begin{array}{l}179,00 \\
2\end{array}$ & & $1,132,781$ & 16747 \\
\hline $\begin{array}{l}\text { Cameroo } \\
n^{6}\end{array}$ & 25.45 & $\begin{array}{l}1,126,33 \\
2\end{array}$ & 43,300 & & $\begin{array}{l}316,55 \\
5\end{array}$ & & 721,000 & 45477 \\
\hline Egypt $^{7}$ & $\begin{array}{l}101.0 \\
5\end{array}$ & $\begin{array}{l}1,649,68 \\
6\end{array}$ & 700 & 2,250 & $\begin{array}{l}1,307 \\
766\end{array}$ & 11,550 & & 327420 \\
\hline Ethiopia $^{8}$ & $\begin{array}{l}109.9 \\
7\end{array}$ & $\begin{array}{l}8,820,43 \\
7\end{array}$ & 57,344 & 166,050 & $\begin{array}{l}1,426 \\
988\end{array}$ & & $7,051,736$ & 118319 \\
\hline Ghana $^{9}$ & 30.06 & 1030563 & 18,292 & & $\begin{array}{l}442,62 \\
1\end{array}$ & 810 & 598,840 & 30,000 \\
\hline Kenya $^{10}$ & 51.13 & $\begin{array}{l}3,186,52 \\
3\end{array}$ & 114,000 & 306,000 & $\begin{array}{l}594,66 \\
0\end{array}$ & & $1,712,676$ & 459187 \\
\hline Malawi $^{11}$ & 19.68 & $\begin{array}{l}1,338,52 \\
3\end{array}$ & 73,000 & 216,000 & $\begin{array}{l}326,96 \\
0\end{array}$ & 1,826 & 670,900 & 49837 \\
\hline
\end{tabular}




\begin{tabular}{|c|c|c|c|c|c|c|c|c|}
\hline $\begin{array}{l}\text { Mozambi } \\
\text { que }^{12}\end{array}$ & 31.35 & $\begin{array}{l}1,836,37 \\
4\end{array}$ & 75,718 & 184,307 & $\begin{array}{l}348,17 \\
9\end{array}$ & & $1,181,686$ & 46484 \\
\hline $\begin{array}{l}\text { Namibia }^{1} \\
3\end{array}$ & 2.63 & 60,456 & 9,861 & 6,660 & 37,390 & & & 6545 \\
\hline Nigeria $^{14}$ & $\begin{array}{l}200.0 \\
1\end{array}$ & $\begin{array}{l}17,983,5 \\
17\end{array}$ & 144,195 & 253,062 & $\begin{array}{l}1,512 \\
520\end{array}$ & & $\begin{array}{l}15,581,40 \\
0\end{array}$ & 492340 \\
\hline $\begin{array}{l}\text { Senegal }{ }^{1} \\
5\end{array}$ & 16.71 & $\begin{array}{l}1,743,50 \\
7\end{array}$ & 1,946 & & $\begin{array}{l}191,22 \\
8\end{array}$ & & $1,523,700$ & 26633 \\
\hline $\begin{array}{l}\text { S/ } \\
\text { Africa }^{16}\end{array}$ & 58.01 & $\begin{array}{l}4,047,13 \\
8\end{array}$ & 623,598 & $1,150,560$ & $\begin{array}{l}1,002 \\
499\end{array}$ & & $1,003,490$ & 266991 \\
\hline $\begin{array}{l}\text { Tanzania } \\
17\end{array}$ & 60.79 & $\begin{array}{l}1,422,20 \\
4\end{array}$ & 88,509 & 81,051 & $\begin{array}{l}759,50 \\
0\end{array}$ & & 420,000 & 73144 \\
\hline Uganda $^{18}$ & 45.62 & $\begin{array}{l}2,500,00 \\
0\end{array}$ & 12,062 & 30,959 & $\begin{array}{l}375,54 \\
0\end{array}$ & & $1,300,000$ & 781439 \\
\hline Total & $\begin{array}{l}815 . \\
37\end{array}$ & $\begin{array}{l}47,643,9 \\
19\end{array}$ & $\begin{array}{l}1,270,80 \\
7\end{array}$ & $2,421,199$ & $\begin{array}{l}9,306, \\
596\end{array}$ & 14,186 & $\begin{array}{l}32,902,47 \\
4\end{array}$ & 1728657 \\
\hline
\end{tabular}

\section{RVVC - recurrent vulvovaginal candidiasis}


Table 2: Description of some fungal infections which are unique to Africa ${ }^{20}$

\begin{tabular}{|c|c|c|}
\hline Disease & Agent & Presentation \\
\hline Entomophthoromycosis & $\begin{array}{l}\text { Conidiobolus } \\
\text { coronatus, } \\
\text { C.incongruous, } \\
\text { Basidiobolus } \\
\text { ranarum }\end{array}$ & $\begin{array}{l}\text { Chronic subcutaneous } \\
\text { zygomycosis of the face } \\
\text { and limbs }\end{array}$ \\
\hline Emergomycosis & $\begin{array}{l}\text { Emergomyces } \\
\text { africanus }\end{array}$ & $\ldots$ \\
\hline African histoplasmosis & $\begin{array}{l}\text { Histoplasmam } \\
\text { duboisii }\end{array}$ & $\begin{array}{l}\text { Skin and subcutaneous } \\
\text { nodules/ abscesses, and } \\
\text { osteomyelitis }\end{array}$ \\
\hline Favus & $\begin{array}{l}\text { Trichosporon } \\
\text { schoenlinii }\end{array}$ & $\begin{array}{l}\text { Crusts of the scalp } \\
\text { (scutulum) in children and } \\
\text { few adolescents }\end{array}$ \\
\hline & & \\
\hline
\end{tabular}




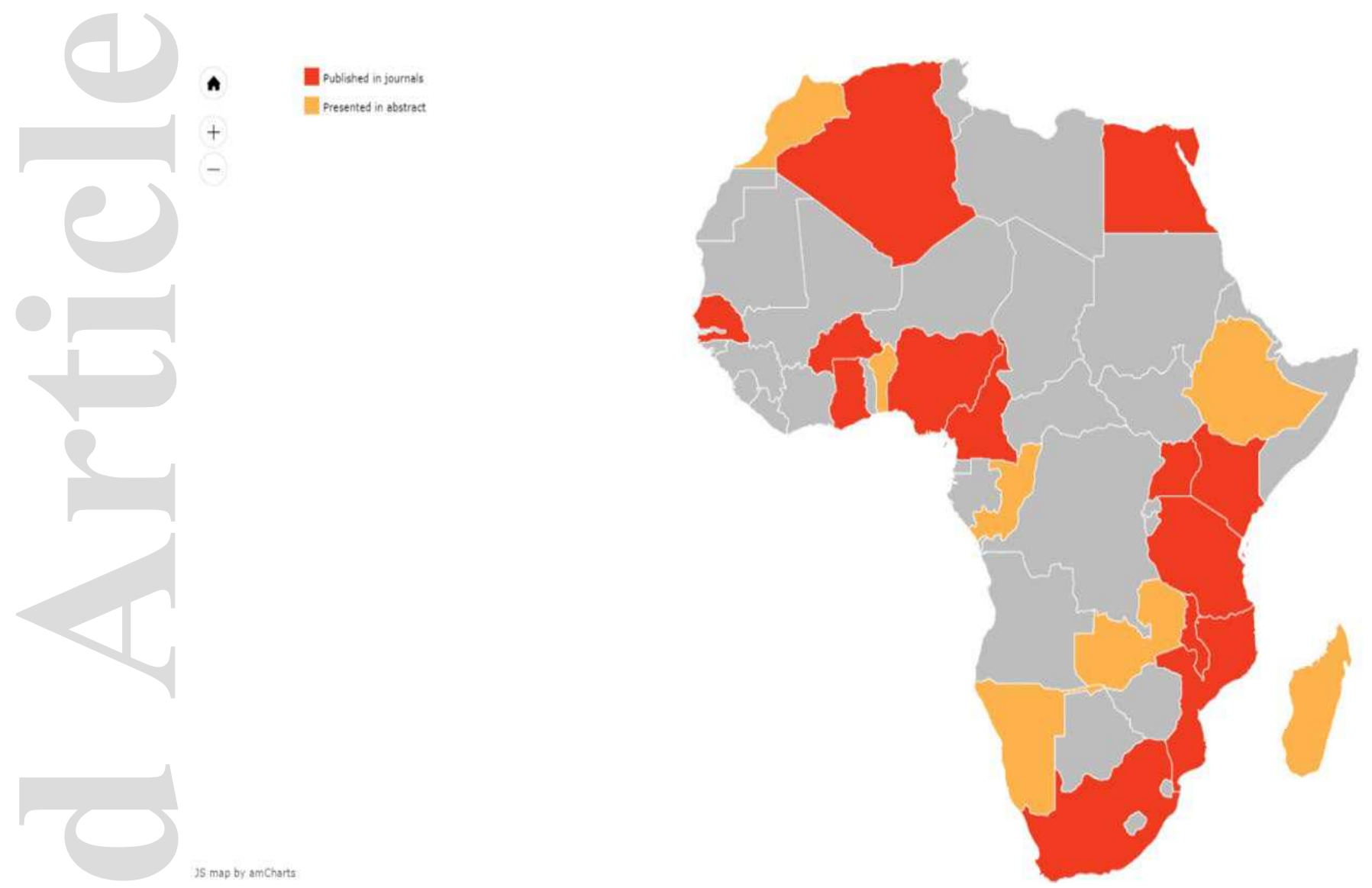

Figure 1: Documented burden of fungal infections across Africa ${ }^{2}$ 